\title{
KURHANY Z EPOKI BRĄZU NAD GÓRNYM DNIESTREM - POLSKO-UKRAIŃSKIE PROJEKTY BADAWCZE
}

\section{BRONZE AGE BARROWS IN THE UPPER DNIESTER BASIN - POLISH-UKRAINIAN RESEARCH PROJECTS}

\author{
Przemystaw Makarowicz \\ Instytut Prahistorii, Uniwersytet im. Adama Mickiewicza \\ ul. Św. Marcin 78, 61-809 Poznań, Poland \\ Siergiej D. Lysenko \\ Instytut Archeologii Narodowej Akademii Nauk Ukrainy \\ ul. Geroiv Stalingrada 12, 254655 Kijów, Ukraine \\ Igor T. Kočkin \\ Katedra Etnologii i Archeologii Instytutu Historii, Politologii i Stosunków Międzynarodowych \\ Przykarpackiego Narodowego Uniwersytetu im. V. Stefanika \\ ul. Ševčenki 57, 76000 Ivano-Frankivs'k, Ukraine
}

\begin{abstract}
This paper discuses the excavations in the cemetery of the Komarów culture of the Bronze Age in Bukivna upon the upper Dniester. They have been carried out by the Polish-Ukrainian archaeological expedition as a part of the project of the National Centre of Sciences, the aim of which has been to provide comprehensive bioarchaeological characteristic and socio-cultural interpretation of the cemetery.

During the field walking over 50 barrows were documented, round or slightly oval in plan. They occurred in three main clusters, arranged in groups-lines, on the watershed between the Dniester and its little, nameless tributary.

The article presents the results of the study of barrow 1, in which there were discovered six features and over 400 artefacts, including 38 vessels in several deposits, 262 flint implements, fragments of structural daub, and bronze items - a pin and pendant, as well as small, burned bones.

Among the features two charred wooden structures seem special and one stone-and-wood (cenotaph). Bones were "scattered" mainly between wooden structures.

A series of analyses and specialist expertises had been done: radiocarbon, paleopedological, geomorphological, paleobotanical, physico-chemical. The sum of probability distribution of calibrated radiocarbon dates suggests second quarter of the second millennium BC. These dates are consistent with the analysis of the stylistics of vessels and bronze artefacts, indicating the early and classic stages of development of the Komarów culture.
\end{abstract}




\section{WPROWADZENIE}

Jednym z wielu kierunków zainteresowań badawczych pracowników Instytutu Prahistorii Uniwersytetu im. Adama Mickiewicza w Poznaniu jest Europa Środkowo-Wschodnia. Na terenie Ukrainy działają obecnie trzy misje archeologiczne, realizujące różne projekty naukowe ${ }^{1}$. Jedną z nich jest ekspedycja górnodniestrzańska, której działalność obejmuje dwa projekty. Pierwszy z nich - „Bukivna ${ }^{2}$. Elitarna nekropola kultury komarowskiej nad Dniestrem" - dotyczy badań terenowych (nieinwazyjnych i wykopaliskowych) oraz analitycznych rozległego cmentarzyska $\mathrm{z}$ epoki brązu, rozpoznanego wstępnie $\mathrm{w}$ latach 30. XX w. przez archeologów z Zakładu Prehistorii Uniwersytetu Jana Kazimierza we Lwowie ${ }^{3}$. Jest on realizowany w ramach grantu Narodowego Centrum Nauki. Drugi projekt, rozpoczęty w 2013 r. i finansowany ze środków Narodowego Programu Rozwoju Humanistyki, nosi tytuł: „Katalog cmentarzysk kurhanowych kultury komarowskiej w dorzeczu górnego Dniestru (dawne województwo stanisławowskie)". Obejmuje inwentaryzację, wykonanie planów sytuacyjno-wysokościowych i map cyfrowych, badania nieinwazyjne oraz sporządzenie katalogu kilkunastu nekropoli znanych z badań przedwojennych.

Niniejszy artykuł dotyczy pierwszego z wymienionych projektów ${ }^{4}$. Przedstawiono w nim w sposób syntetyczny wstępne wyniki badań wspólnej, polsko-ukraińskiej ekspedycji archeologicznej. Zainicjowała ona swoją działalność w 2009 r. zakrojoną na dużą skalę prospekcją terenową, podczas której zarejestrowano dwa zgrupowania kurhanów, znajdujące się w lesie bukowym ${ }^{5}$. Udokumentowano także ślady po kopcu zbadanym w 1937 r., usytuowanym przy byłym dworze Wojciecha Komornickiego, przedwojennego właściciela Bukównej, i jeden kurhan przy kościele (obecnie cerkwi prawosławnej) we wsi.

W lipcu 2010 r. podjęto badania wykopaliskowe dwóch kurhanów z grupy I. Uczestniczyli w nich naukowcy i studenci z Instytutu Prahistorii UAM w Poznaniu, Instytutu Archeologii Narodowej Akademii Nauk Ukrainy w Kijowie oraz Katedry Etnologii i Archeologii Instytutu Historii, Politologii i Stosunków Międzynarodowych Narodowego Przykarpackiego Uniwersytetu im. V. Stefanika w Ivano-

\footnotetext{
${ }^{1}$ Szerzej: Kośko 2011; Makarowicz 2012; Makarowicz, Lysenko, Kočkin 2013.

${ }^{2} \mathrm{~W}$ pracy zastosowano transliterację nazw własnych pisanych $\mathrm{w}$ alfabecie ukraińskim oraz ich spolszczanie według zasad sformułowanych w Nowym słowniku ortograficznym PWN (1999). W przypadku miejscowości, w których prowadzono badania przed drugą wojną światową, uwzględniano też ich nazwy funkcjonujące we wcześniejszej literaturze (por. Sulimirski 1968).

${ }^{3}$ Bryk 1932; Rogozińska 1959; Siwkówna 1937; Sulimirski 1968; Swiesznikow 1967.

${ }^{4}$ Projekt został sfinansowany ze środków Narodowego Centrum Nauki, przyznanych na podstawie decyzji numer DEC-2011/03/B/HS3/00839.

${ }^{5}$ Por. omówienie ówczesnego programu badań - Makarowicz 2012.
} 
-Frankivs'ku'. Całkowicie ukończono eksplorację kurhanu 1, ratowniczo natomiast rozpoznano kopiec 2 - w jego centrum zaobserwowano świeży wkop rabunkowy. W trakcie weryfikacyjnych badań powierzchniowych poprzedzających etap wykopaliskowy udokumentowano trzecią grupę kurhanów, usytuowaną w lesie bukowym, w odległości około $1 \mathrm{~km}$ na południowy zachód od pierwszego oraz na północny zachód od drugiego skupiska. W 2011 r. skoncentrowano się na badaniach środowiskowych i pobieraniu próbek z kurhanów oraz otoczenia cmentarzyska. Prospekcję wykopaliskową kontynuowano w 2012 r., dzięki wsparciu projektu wspomnianym grantem NCN. Sformułowano wówczas ostateczne ramy obszerniejszego programu badawczego. Jego celem jest kompleksowa charakterystyka bioarcheologiczna i interpretacja społeczno-kulturowa nekropoli w Bukivnej. Wyniki badań wykopaliskowych i nieinwazyjnych (geomagnetycznych) wybranych kopców oraz analizy specjalistyczne materiału archeologicznego i przyrodniczego umożliwią poznanie jej organizacji przestrzennej, chronologii udokumentowanych grup kurhanowych i wybranych kopców oraz interpretację struktury społecznej użytkowników cmentarzyska. Możliwa będzie rekonstrukcja dynamiki przestrzennego rozwoju nekropoli oraz poznanie budowy i sposobu wznoszenia kopców. Analiza kontekstu środowiskowego (dolina Dniestru) oraz opracowanie źródeł przyrodniczych uzyskanych w trakcie prospekcji terenowych umożliwią rekonstrukcję paleośrodowiska otoczenia cmentarzyska. Realizacja wymienionych zadań stworzy podstawy rekonstrukcji życia rytualnego związanego z obrzędami ,przejścia w zaświaty” użytkowników cmentarzyska - elit kultury komarowskiej - i sposobami organizowania przez nie przestrzeni społeczno-kulturowej ${ }^{7}$. Dzięki temu możliwa będzie weryfikacja hipotezy o znacznej dyferencjacji społecznej omawianych społeczności, czego materialnym wyrazem było pojawienie się bogato wyposażonych pochówków w grobach podkurhanowych ${ }^{8}$.

\section{USYTUOWANIE CMENTARZYSKA I UKŁAD PRZESTRZENNY KURHANÓW}

Nekropola w Bukivnej - jeden z największych obiektów tego typu w całym trzcinieckim kręgu kulturowym - znajduje się nad górnym Dniestrem, w odległości około $1,5 \mathrm{~km}$ od koryta rzeki, na prawym, wysokim brzegu (ryc. 1). W regionaliza-

\footnotetext{
${ }^{6}$ Badaniami kierowali ze strony polskiej - prof. UAM dr hab. Przemysław Makarowicz, ze strony ukraińskiej - dr Siergiej Lysenko i dr Igor Kočkin. Wzięli w nich udział studenci z obu wymienionych uniwersytetów oraz Instytutu Archeologii Uniwersytetu Łódzkiego (por. Lysenko, Makarowicz, Kočkin, Šklarevskij 2011).

${ }^{7}$ Por. Svešnikov 1968; Górski 1996, 2010; Kempisty 1967, 1978; Florek, Taras 2003; Makarowicz 2008, 2009, 2010a, 2010b; Lysenko, Makarowicz 2013; Makarowicz, Lysenko, Kočkin 2013.

${ }^{8}$ Sulimirski 1964, 1968, 105-121; Makarowicz 2008, 2009, 332-337; 2010b, 311-317.
} 
cji fizyczno-geograficznej teren ów jest fragmentem Przedkarpacia, graniczącym od północy z Wyżyną Podolską, a pod względem regionalizacji etnograficznej leży on w Galicji ${ }^{9}$. Pod względem administracyjnym nekropola znajduje się w rejonie tłumackim obwodu ivano-frankivs'kiego. Kurhany występują w trzech zasadniczych skupiskach, ciągnących się z północy na południe wzdłuż wsi Bukivna, w odległości około 1,5-2 km na zachód od jej zabudowań, na wododziale między Dniestrem i jego niewielkim, bezimiennym dopływem (ryc. 1).

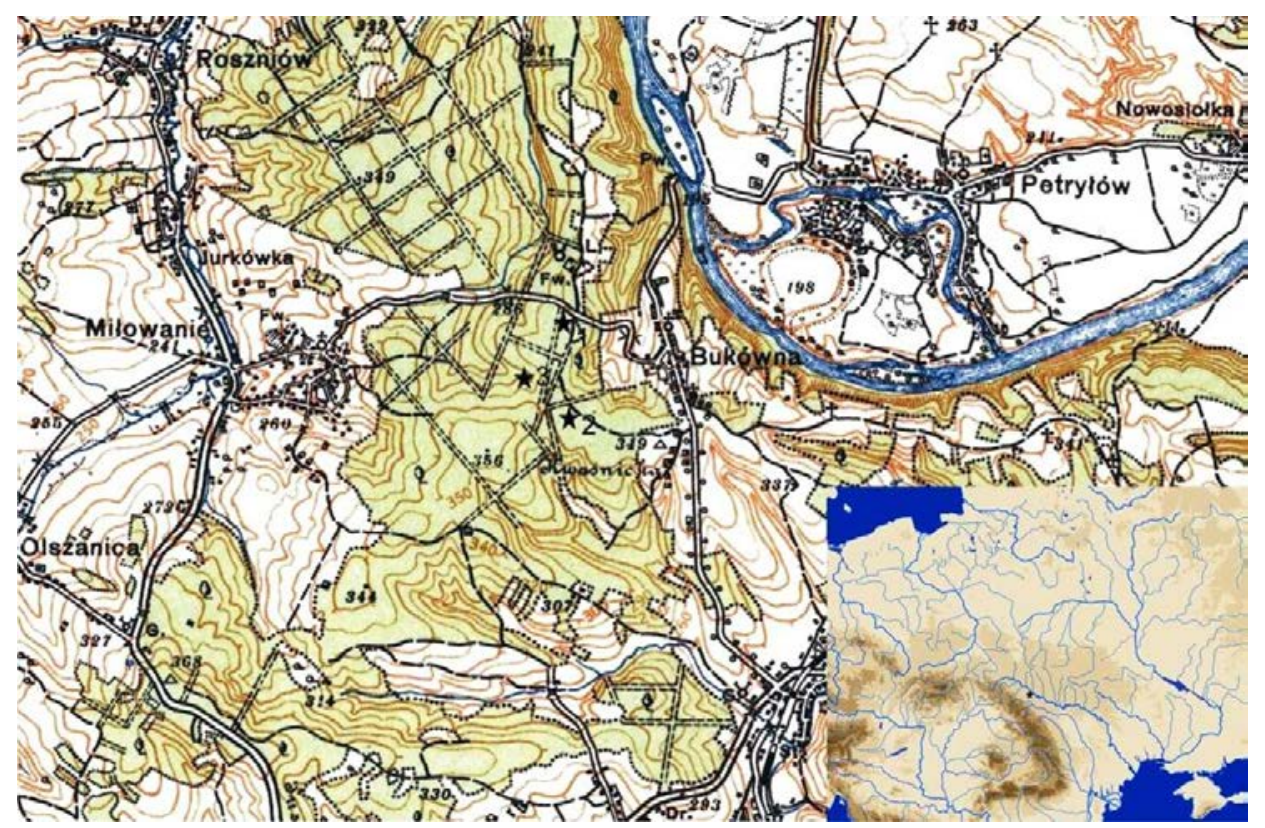

Ryc. 1. Położenie cmentarzyska w Bukivnej (Bukównej), rej. tłumacki, obw. ivano-frankivs'ki, Ukraina, na przedwojennej mapie 1:100 000 (WIG). Ukazano tylko trzy zasadnicze grupy kurhanowe

Fig. 1. Cemetery in Bukivn (Bukówna), Tlumač reg., Ivano-Frankivsk Prov., Ukraine, on a pre-war map $1: 100000$ (WIG). Only three main concentrations of barrows were marked

W ramach wspomnianych koncentracji kopce wzniesiono w układzie liniowym (liniowo-grupowym). Odległość między I i II grupą wynosi $850 \mathrm{~m}$, natomiast między I i III oraz II i III - około $1 \mathrm{~km}$. W kilku przypadkach widoczna jest - zaobserwowana już przez J. Bryka ${ }^{10}$ - specyficzna aranżacja kopców, tj. ich koncentracja po trzy (mniejsze kurhany wokół większego), jednak wzdłuż określonej linii. Obiekty te usytuowane są na osi północ - południe (I grupa), wschód-zachód (II grupa) oraz północny wschód-południowy zachód (grupa III). Zarówno wzniesienie kurhanów na

\footnotetext{
${ }^{9}$ Kusiński, Zastavnyj 2003; Gudowski (red.) 2007; Zagalnogegrafičnyj atlas... 2004.

${ }^{10}$ Bryk 1932, 22.
} 
wododziale, jak i ich układ przestrzenny jest charakterystyczny dla cmentarzysk kurhanowych kręgu trzcinieckiego, zwłaszcza w jego południowej odmianie. Nietypowa jest jednak nieobecność kopców społeczności kultury ceramiki sznurowej, zazwyczaj bowiem obiekty „komarowskie” wkomponowywano we wcześniejsze układy kurhanów „sznurowych" ${ }^{11}$. W tym przypadku wszystkie rozpoznane dotąd wykopaliskowo obiekty (łącznie z badaniami z lat 30. XX w.) należały do „komarowskiej” odmiany trzcinieckiego kręgu kulturowego (kultury/grupy komarowskiej). Polsko-ukraińska ekspedycja udokumentowała prawie 40 kurhanów. Uwzględniając odkrycia przedwojenne, należy sądzić, że pierwotnie nekropola (nekropole?) bukivniańska liczyła ponad 50 obiektów, okrągłych lub owalnych w planie.

W ramach trzech udokumentowanych koncentracji kopców odnotowano: w grupie I i II - po 13, w III - 10 kurhanów $^{12}$. Dwa kolejne obiekty zaobserwowano w odległości około $600 \mathrm{~m}$ na północ od grupy I, następny zarejestrowano w południowej części wsi. Podczas prospekcji powierzchniowej natrafiono na ślady po wyeksplorowanym przez archeologów z UJK we Lwowie kopcu $\mathrm{VI}^{13}$, znajdujące się między kurhanami 12 i 13 wspomnianej koncentracji.

W pierwszym skupisku (ryc. 2) występują obiekty o średnicy od kilkunastu do dwudziestu kilku metrów i wysokości od 0,5 do około $2 \mathrm{~m}$. Wzniesiono je $w$ układzie liniowym na przestrzeni ponad $320 \mathrm{~m}$, niemal na osi N-S. Kopce usypano w mniejszych zgrupowaniach: północnym, środkowym (po pięć kopców) i południowym (trzy obiekty). Odległości między nimi wynoszą odpowiednio 90 i $50 \mathrm{~m}$. Interesujący ,zdwojony” układ tworzą dwa kurhany (6 i 7) znajdujące się w południowej części północnego zgrupowania. Trójkowe

Ryc. 2. Bukivna, rej. tłumacki, obw. ivano-frankivs'ki. Plan sytuacyjno-wysokościowy grupy kurhanowej I (wyk. Marina Daragan)

Fig. 2. Bukivna, Tlumač reg., Ivano-Frankivsk Prov. Contour plan of barrow concentration I (after Marina Daragan)
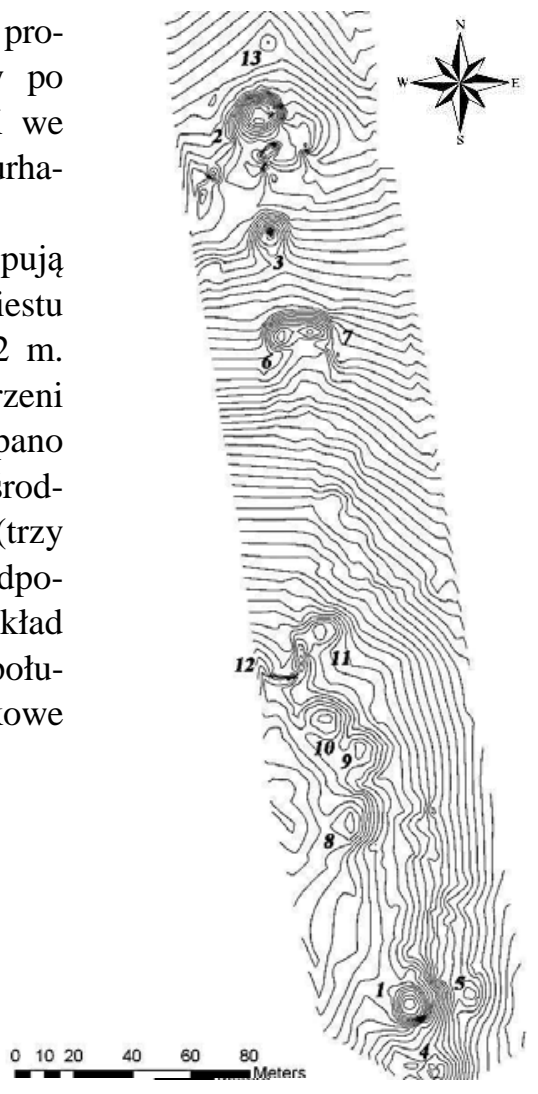

\footnotetext{
${ }^{11}$ Makarowicz 2010b, 71; 2010a, 201.

${ }^{12}$ Niepewna jest identyfikacja kurhanów w części NE planu sytuacyjno-wysokościowego. Sytuację wyjaśnią nowe badania terenowe.

${ }^{13}$ Siwkówna 1937, 69.
} 
układy tworzą obiekty 8, 9 i 10, oraz 12, 13 i VI/1937, zaobserwowane w centrum omawianej grupy. Odległości między najbliższymi sobie kurhanami liczą od kilku do kilkudziesięciu metrów.

W drugiej grupie (ryc. 3) zarejestrowano również 13 kopców, występujących w układzie liniowym na osi W-E, w pasie o długości około $300 \mathrm{~m}$. Tutaj także można wyróżnić ich mniejsze zgrupowania: cztery kurhany zaobserwowano na północy, sześć w centrum i trzy w partii południowej wzmiankowanej koncentracji. Odległości między skupiskami wynoszą odpowiednio około 40 i $80 \mathrm{~m}$. W tej grupie udokumentowano dwa kopce wyróżniające się wielkością. Mierzą one ponad $3 \mathrm{~m}$ wysokości oraz odpowiednio 12 (nr 1) i $22 \mathrm{~m}$ (nr 2) średnicy. Pozostałe są znacznie niższe i liczą od $0,5 \mathrm{~m}$ do nieco ponad $1 \mathrm{~m}$ wysokości oraz od 10 do $16 \mathrm{~m}$ średnicy. Trójkowe położenie tworzą kopce 9, 10 i 11 w części północnej oraz 1, 3 i 4 w centrum omawianej grupy.

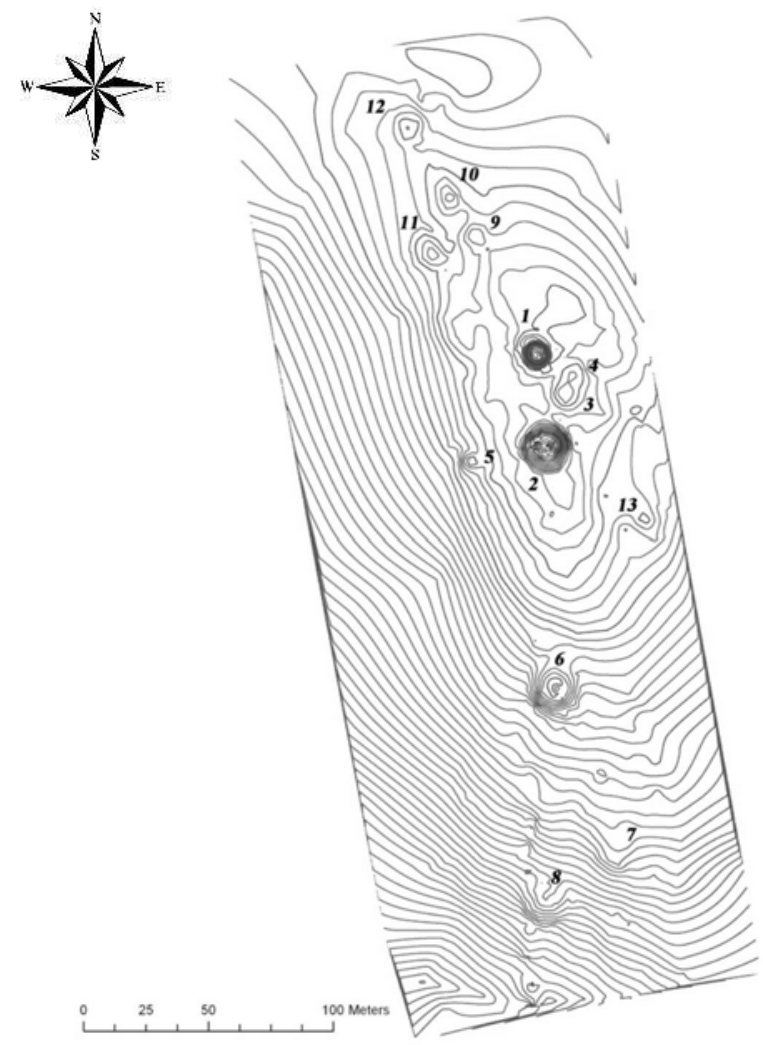

Ryc. 3. Bukivna, rej. tlumacki, obw. ivano-frankivs'ki. Plan sytuacyjno-wysokościowy grupy kurhanowej II (wyk. Marina Daragan)

Fig. 3. Bukivna, Tlumač reg., Ivano-Frankivsk Prov. Contour plan of barrow concentration II (after Marina Daragan) 
Trzecie skupisko (ryc. 4) liczy prawdopodobnie 10 kurhanów, choć ich ostateczną liczbę trzeba jeszcze zweryfikować ze względu na znaczne deniwelacje terenu i występowanie w tym rejonie głębokich jarów. Rozciąga się ono - podobnie jak dwa uprzednie - na przestrzeni około $300 \mathrm{~m}$ na linii NE-SW. Kopce występują w dwóch koncentracjach: północno-zachodniej (cztery obiekty) i południowo-wchodniej (sześć obiektów). Odległość między nimi wynosi około $150 \mathrm{~m}$. Największe kurhany mają ponad $2 \mathrm{~m}$ wysokości i około $20 \mathrm{~m}$ średnicy. Odległości między najbliższymi obiektami wynoszą od kilku do ponad $30 \mathrm{~m}$.

W niniejszym artykule przedstawiono wyniki badań pierwszego kurhanu, rozpoznanego wykopaliskowo w $2010 \mathrm{r}$.

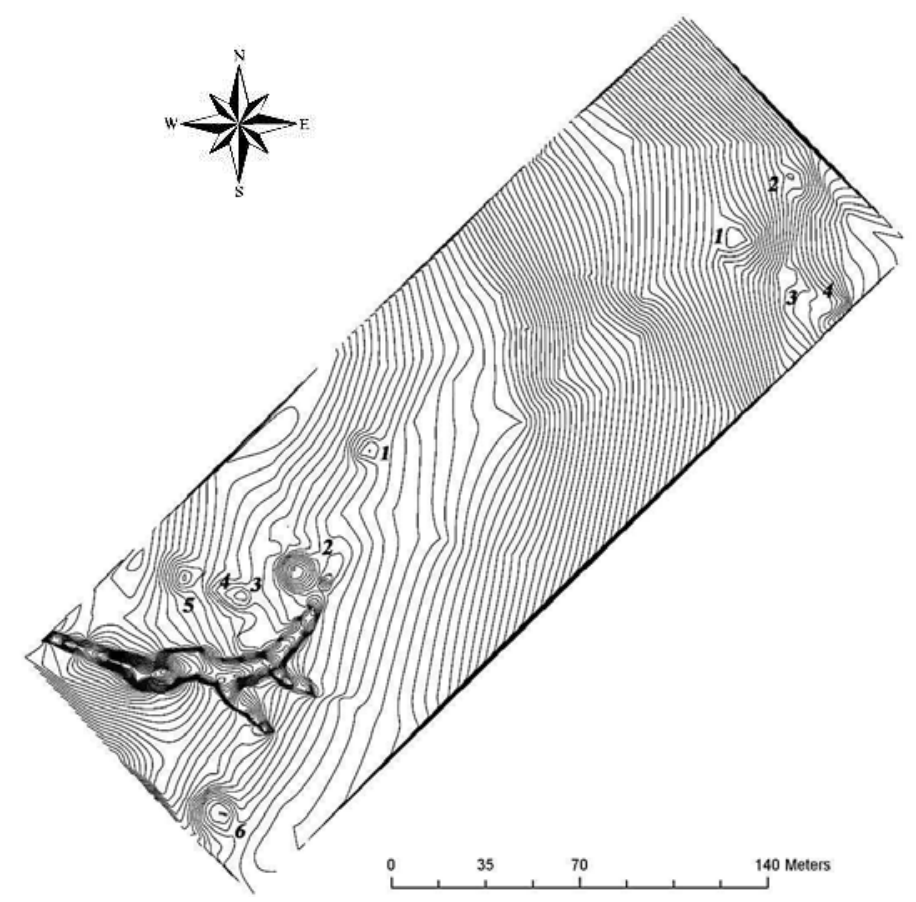

Ryc. 4. Bukivna, rej. tłumacki, obw. ivano-frankivs'ki. Plan sytuacyjno-wysokościowy grupy kurhanowej III (wyk. Marina Daragan)

Fig. 4. Bukivna, Tlumač reg., Ivano-Frankivsk Prov. Contour plan of barrow concentration III (after Marina Daragan)

\section{KURHAN 1 - WSTĘPNE REZULTATY BADAŃ}

Kurhan 1 udokumentowano w południowej części pierwszej z wymienionych grup kopców, w lesie bukowym przy polnej drodze prowadzącej z kościoła do dawnego dworu, około $250 \mathrm{~m}$ na południe od dawnej drogi gruntowej z Bukivnej do Milovania (ryc. 1). 
Przed przystąpieniem do prac usunięto z powierzchni kurhanu drzewa i runo leśne. Kopiec eksplorowano za pomocą sprzętu ręcznego, warstwami mechanicznymi o miąższości $25-30 \mathrm{~cm}$. W celu kontrolowania profili pozostawiono świadki o szerokości $1 \mathrm{~m}$, usytuowane na liniach N-S i E-W. Po wyeksplorowaniu każdej warstwy czyszczono jej spąg, rejestrując obiekty nieruchome oraz ważne interpretacyjnie warstwy konsystencyjne. Źródła ruchome dokumentowano trójwymiarowo; do pomiarów głębokości wykorzystywano niwelator. W trakcie prac używano także wy-
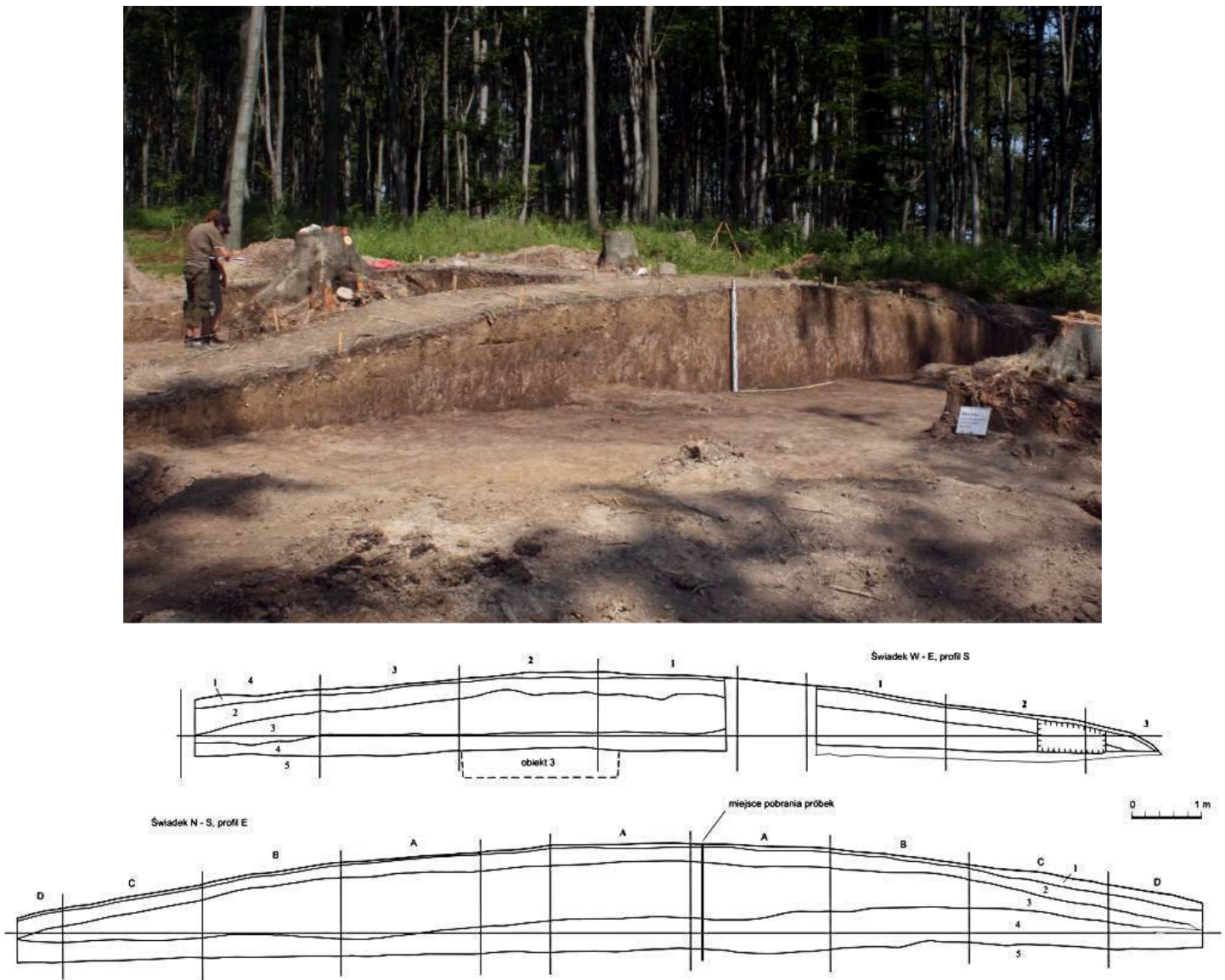

Ryc. 5. Bukivna, rej. tłumacki, obw. ivano-frankivs'ki. Kurhan 1. U góry - widok od południowego wschodu. Na dole - stratygrafia kopca. 1 - próchnica współczesna; 2 - jasnoszary less; 3 - nasyp kurhanu zbudowany z kawałków/cegiełek darni (,przekładka wałków”); 4 - czarno-brunatna próchnica pierwotna; 5 - szarawo-brunatny less

Fig. 5. Bukivna, Tlumač reg., Ivano-Frankivsk Prov. Barrow 1. At the top - view from S-E. At the bottom - stratigraphy of a barrow 1 - contemporary humus; 2 - light grey loess; 3 - embankment of the barrow built of pieces of turf ("rolled divider"); 4 - black and brown primary humus; 5 - grey and brown loess 
wykrywacza metalu. Wykonywano standardową dokumentację opisową oraz graficzną w skali $1: 20$ i $1: 10$, a także dokumentację fotograficzną.

Kurhan znajdował się na szczycie niewielkiego naturalnego wzniesienia. W rzucie poziomym był owalny, zorientowany na osi NNE-SSW, o wymiarach $15 \times 13 \mathrm{~m}$ i wysokości 1,3 m. Wokół niego, zwłaszcza od strony południowej i zachodniej, widoczne było półkoliste zagłębienie, o szerokości 4-5,5 m, skąd brano darń do jego budowy. Układ stratygraficzny kopca był następujący. W jego stropie występowała kilkucentymetrowa warstwa próchnicy współczesnej, pod nią warstwa jasnoszarego lessu o miąższości $20-40 \mathrm{~cm}$. Poniżej znajdował właściwy nasyp o miąższości maksymalnej około $90 \mathrm{~cm}$. Był on zbudowany z wałków-cegiełek darni (ros. „wałkowa

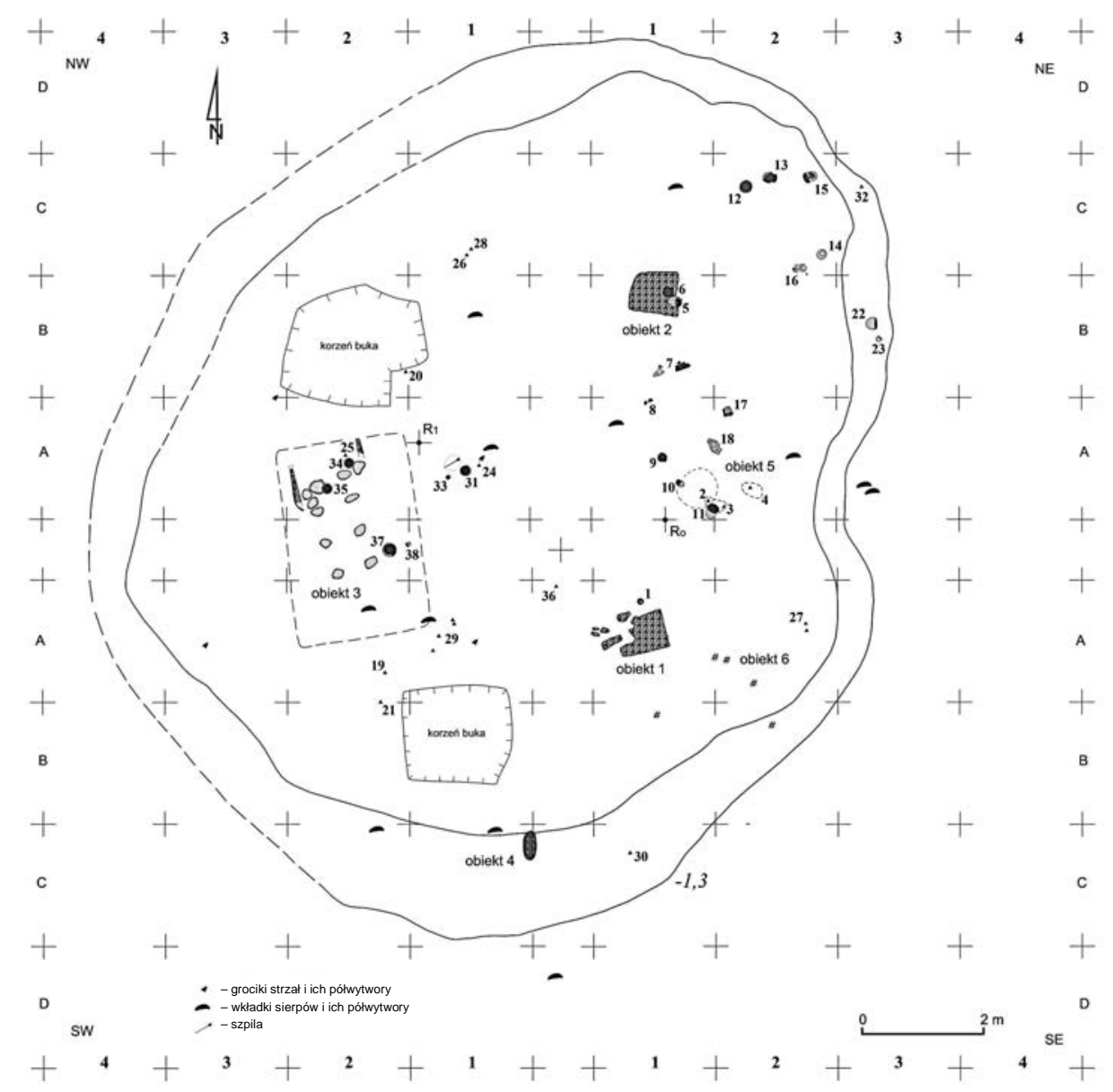

Ryc. 6. Bukivna, rej. tłumacki, obw. ivano-frankivs'ki. Plan kurhanu na głębokości około 1,3 m. $1-38$ - naczynia

Fig. 6. Bukivna, Tlumač reg., Ivano-Frankivsk Prov. Plan of a barrow at the depth of about $1.3 \mathrm{~m}$. $1-38-$ vessels 
kładka" - przekładka wałków) o barwie brunatnej i brunatno-ciemnoszarej, wyciętych wokół kurhanu i przylegających do siebie w płaszczyźnie horyzontalnej i wertykalnej. W spągu znajdowała się jednolicie czarno-brunatna warstwa próchnicy pierwotnej o miąższości około $60 \mathrm{~cm}$, pod którą występowała skała macierzysta less o gliniastej konsystencji (ryc. 5).

Na różnej głębokości, w płaszczu kopca i na poziomie próchnicy pierwotnej, zarejestrowano sześć obiektów nieruchomych i ponad 400 źródeł ruchomych, w tym 38 naczyń w kilkunastu depozytach, fragmenty ceramiki innych pojemników, 262 wyroby krzemienne, fragmenty polepy konstrukcyjnej, wyroby z brązu - szpilę i zawieszkę oraz drobne przepalone kości (ryc. 6).

\section{Obiekty nieruchome}

W tej kategorii źródeł udokumentowano dwie konstrukcje drewniane (l i 2 ), jedną kamienno-drewnianą (3), pozostałość „wyściółki” z kamieni rzecznych (4), jamę (5) oraz relikty konstrukcji zbudowanej z polepy o prostych ściankach (6).

W południowo-wschodnim sektorze kurhanu, na głębokości 1,1-1,25 m, w stropie próchnicy pierwotnej, odnotowano obiekt 1 (ryc. 6). Była to spalona konstrukcja drewniana zbudowana z desek zorientowanych wzdłuż linii WSW-ENE. W planie

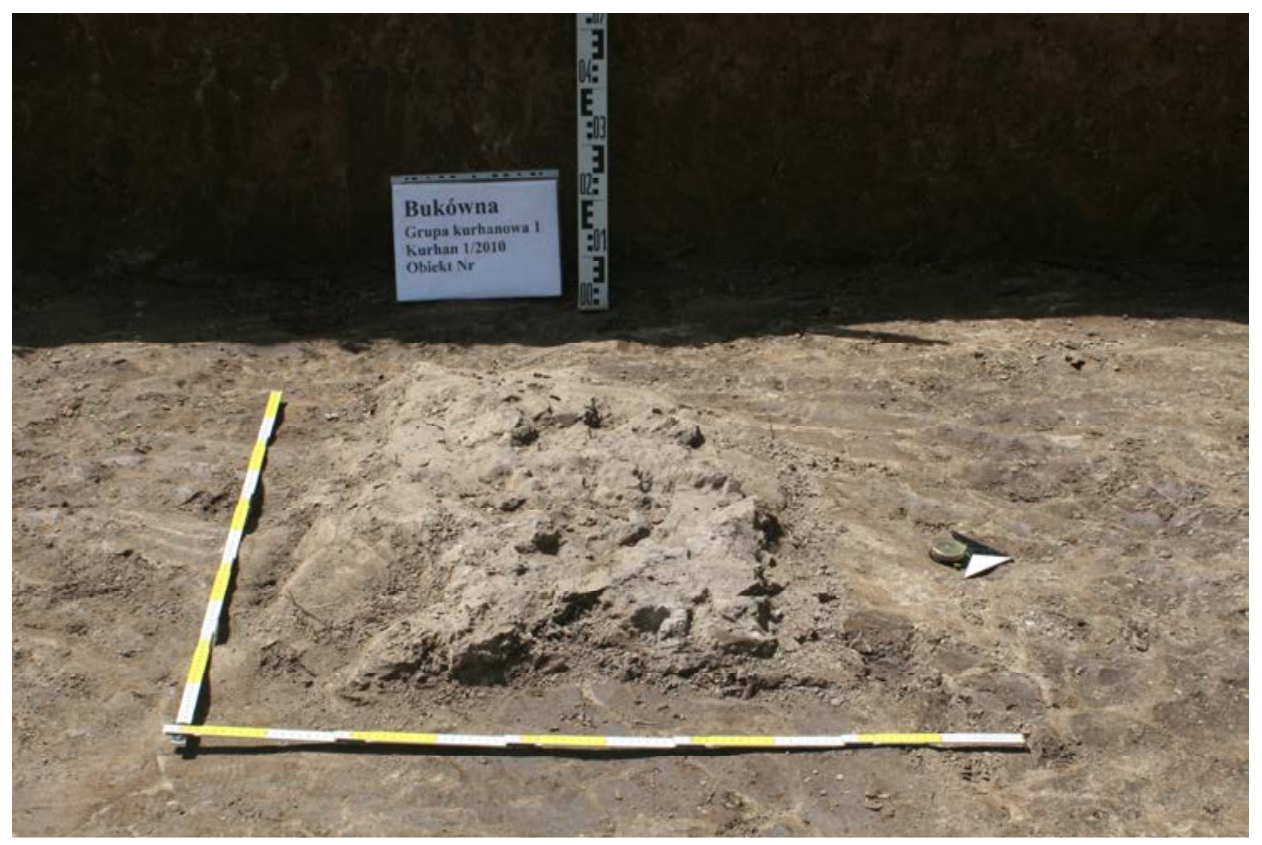

Ryc. 7. Bukivna, rej. tłumacki, obw. ivano-frankivs'ki. Kurhan 1, sektor NE, obiekt 2

Fig. 7. Bukivna, Tlumač reg., Ivano-Frankivsk Prov. Barrow 1, area NE, feature 2 
płaskim była niemal prostokątna (wymiary: $1,1 \times 0,5-0,7 \mathrm{~m}$, grubość około $3 \mathrm{~cm}$ ). W części północnej obiektu znajdowało się naczynie. Na południe od wspomnianego pojemnika, w odległości 1,6 m zarejestrowano skupisko węgli.

W sektorze północno-wschodnim kopca, na głębokości ponad $1 \mathrm{~m}$, na pograniczu nasypu i próchnicy pierwotnej, udokumentowano obiekt 2, o analogicznej strukturze
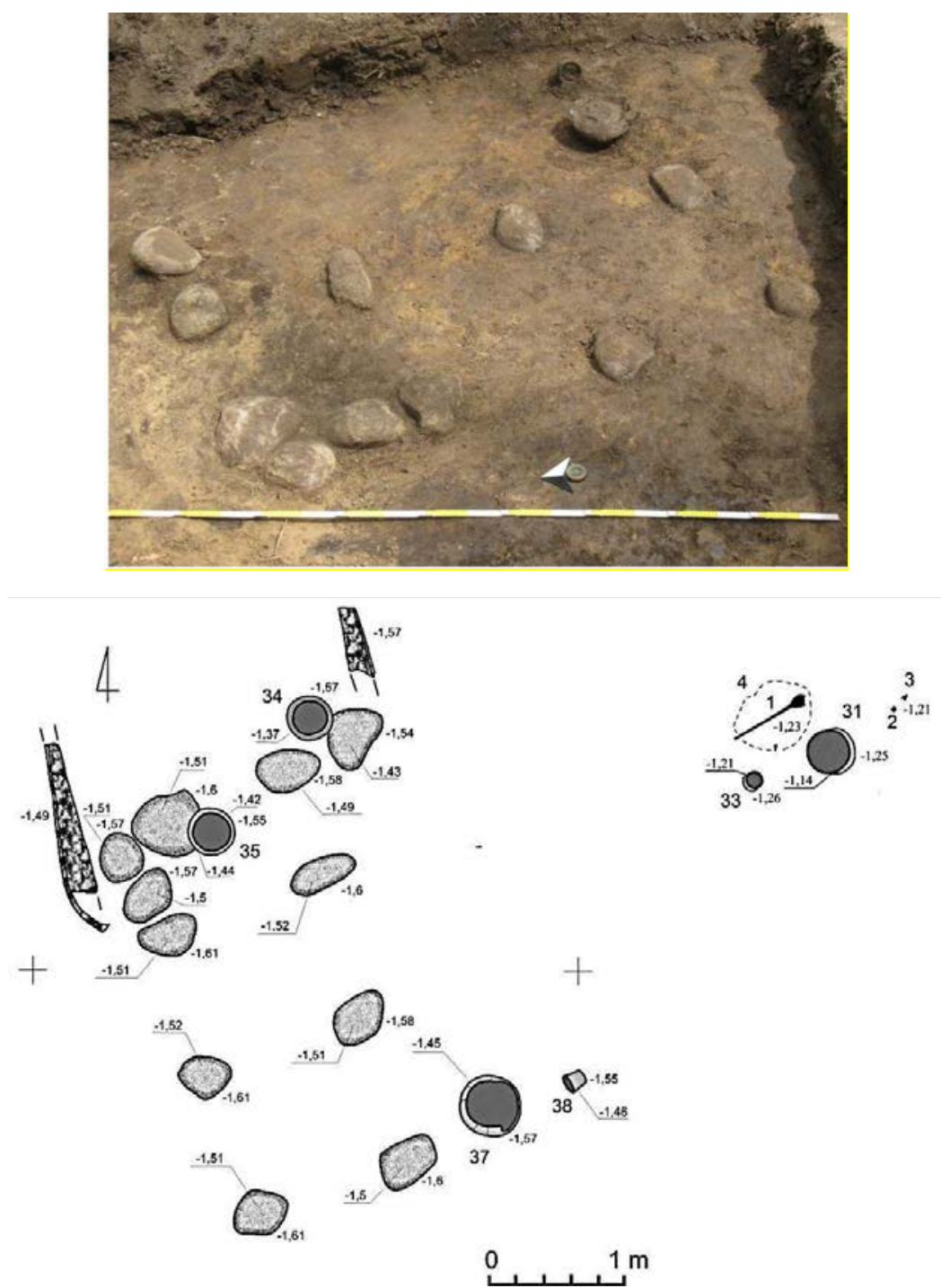

Ryc. 8. Bukivna, rej. tłumacki, obw. ivano-frankivs'ki. Kurhan 1, sektor W, obiekt 3 (u góry) oraz obiekt 3 i depozyt ze szpilą (na dole)

Fig. 8. Bukivna, Tlumač reg., Ivano-Frankivsk Prov. Barrow 1, area W, feature 3 (top), feature 3 and a deposit with a pin (bottom) 
jak poprzedni (ryc. 6 i 7). Była to drewniana, spalona konstrukcja o kształcie zbliżonym do prostokąta (wymiary: $0,8 \times 0,7 \mathrm{~m}$, grubość około $3 \mathrm{~cm}$ ). Resztki desek zorientowane były wzdłuż linii W-E. We wschodniej części obiektu ustawiono dwa naczynia.

W zachodniej części kurhanu, w płytkiej prostokątnej jamie o wymiarach $3 \times 2,2 \mathrm{~m}$, zbudowano konstrukcję kamienno-drewnianą (obiekt 3), zorientowaną na osi NNW-SSE (ryc. 6 i 8). W rzucie poziomym miała ona kształt zbliżony do prostokąta o wymiarach $1,7 \times 0,9-0,8 \mathrm{~m}$. Zarys konstrukcji tworzyły owalne kamienie morenowe oraz fragmenty desek. Dziesięć kamieni ułożono równolegle w dwa rzędy. Pojedynczy eratyk, usytuowany od strony północno-wschodniej, współtworzył swego rodzaju przedsionek. W północnej części obiektu, po obu jego stronach, zaobserwowano resztki spalonych desek o zachowanej długości $0,7 \mathrm{~m}$, szerokości około $10 \mathrm{~cm}$ i grubości $2-3 \mathrm{~cm}$. Na ich przedłużeniu znajdowały się niewielkie skupiska węgli. W obiekcie zarejestrowano cztery naczynia - po dwa w partii północnej oraz południowo-wschodniej. W obiekcie nie odnotowano kości, stąd uznano go wstępnie za kenotaf ${ }^{14}$.

Obiekt 4 udokumentowano w południowo-zachodnim sektorze kopca, na głębokości 1,45-1,5 m od jego stropu (ryc. 6). Była to cienka warstewka („wyściółka”) drobnych kamyków rzecznych o wymiarach $0,43 \times 0,2 \mathrm{~m}$, bez materiału archeologicznego.

W północno-wschodnim sektorze kurhanu, na głębokości około $1 \mathrm{~m}$, odkryto obiekt 5 (ryc. 7) - kolistą, jaśniejszą od otoczenia jamę, o średnicy 0,65 m i głębokości 0,22 m. Zarejestrowano w niej kilkanaście drobnych przepalonych kości.

W południowo-wschodniej ćwiartce kopca, na głębokości 1,30-1,35 m od jego stropu udokumentowano obiekt 6 , usytuowany niemal bezpośrednio na calcu (ryc. 6). Reprezentowało go skupisko kilku dużych fragmentów polepy konstrukcyjnej o prostej powierzchni niektórych ścianek, usytuowane na przestrzeni o powierzchni 1,8 $\times 0,4 \mathrm{~m}$ wzdłuż osi NW-SE. Największe fragmenty polepy o wielkoci $18 \times 10 \times 8$ i $12 \times 8 \times 5 \mathrm{~cm}$, przypominały destrukty domów kultury trypolskiej (fragmenty płoszczadek).

Ponadto w różnych sektorach kurhanu, w niższych warstwach nasypu, rejestrowano niewielkie warstewki węgla drzewnego. Ślady spalenizny w postaci przepalonych węgielków zaobserwowano w sektorze południowo-wschodnim (kwadrat $\mathrm{B} / 2)$. Na głębokości $1,12 \mathrm{~m}$ udokumentowano tu cienką warstewkę węgla drzewnego o rozmiarach $0,2 \times 0,13 \mathrm{~m}$. Podobną, o wymiarach $0,2 \times 0,1 \mathrm{~m}$, odkryto w sektorze północno-zachodnim (kwadrat A/2), na głębokości 0,98 m. Resztki takiej warstewki o grubości $1 \mathrm{~cm}$ odnotowano także w wymienionym sektorze w kwadra$\operatorname{cie} \mathrm{A} / 1$.

\footnotetext{
${ }^{14}$ Gleba z obiektu jest obecnie przedmiotem analizy na zawartość fosforu.
} 


\section{Źródła ruchome}

W nasypie kurhanu, na różnej głębokości odkryto 38 naczyń, z których znaczna część była zachowana w całości lub w większych fragmentach (ryc. 9). Odnotowano je w kilkunastu depozytach w różnych miejscach nasypu kurhanu oraz w obiektach

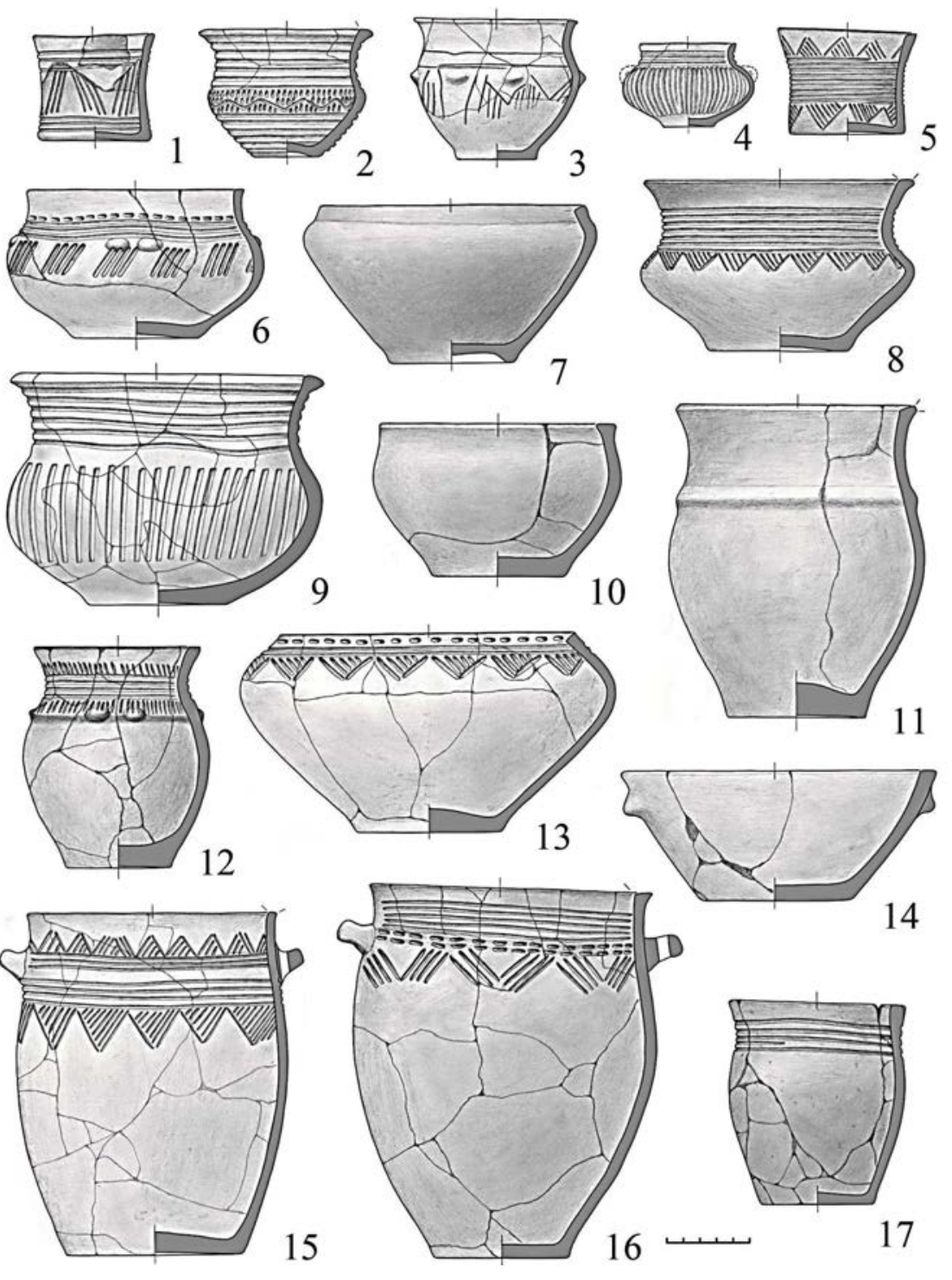

Ryc. 9. Bukivna, rej. tłumacki, obw. ivano-frankivs'ki. Naczynia z kurhanu 1 (wybór) Fig. 9. Bukivna, Tlumač reg., Ivano-Frankivsk Prov. Vessels from barrow 1 (selection) 
(ryc. 6 i ryc. 10). Większa część naczyń była rozmieszczona w dwóch rzędach u podstawy kurhanu, na poziomie próchnicy pierwotnej, między spalonymi konstrukcjami drewnianymi (obiekty 1 i 2). Naczynia złożono też na wspomnianych konstrukcjach (obiekty 1 i 2), a także na północny wschód od obiektu 2 (ryc. 6). Niektóre pojemniki $(22,23,27,30,32)$ zdeponowano (w całości lub rozbite) półkolem od wschodniej strony wzniesienia, zapewne na powierzchni kurhanu. Część z nich rozbito w trakcie budowy nasypu (36), niekiedy blisko stropu $(2,3,4)$, a więc w ostatniej fazie jego wznoszenia. Cztery pojemniki $(34,35,37,38)$ zarejestrowano w kenotafie obiekcie 3 (ryc. 6 i 8). Trzy naczynia $(24,31,33)$ zdeponowano na poziomie próchnicy pierwotnej (1,25 m od wierzchołka kurhanu), na wschód od jamy, w której umieszczono wspomnianą konstrukcję. Stały one w linii, prostopadle do wschodniej ściany konstrukcji. Równolegle do linii wyznaczonej przez naczynia, nieco na północ, złożono brązową szpilę z płytkową główką romboidalną. Obok pojemnika najbardziej oddalonego od kenotafu odkryto krzemienny grocik strzały i zniszczoną ozdobę z brązu (dużą zawieszkę z blaszki?). Pod szpilą udokumentowano ślady substancji organicznej wyznaczającej na oczyszczonym poziomie nierównomierny kontur ciemniejszej ziemi o wymiarach 0,3 × 0,2 m. Na tej samej głębokości złożono kolejne naczynia - na północ $(20)$ i południe $(19,21)$ od kenotafu. Naczynie 25 zdeponowano nad północną częścią jamy, w której był grób, już po jej zasypaniu.

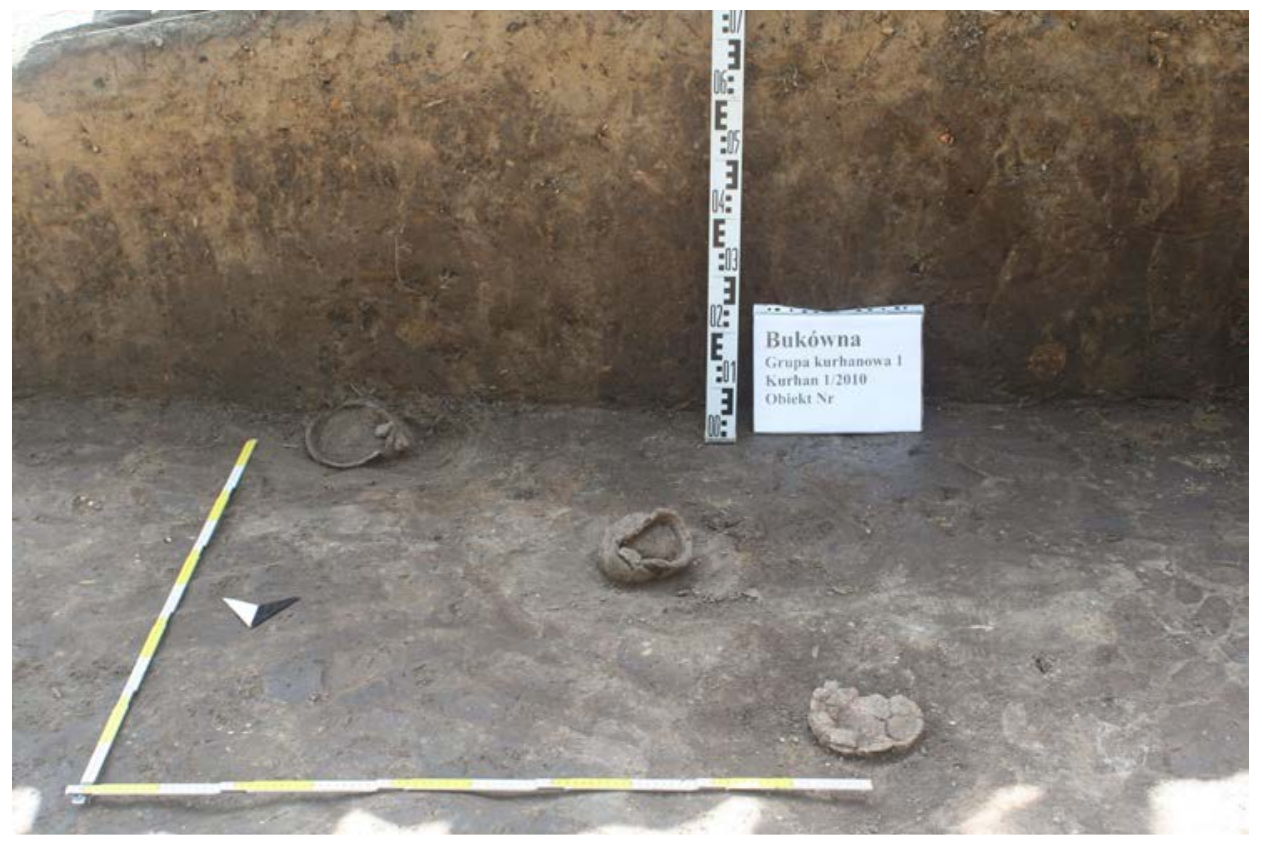

Ryc. 10. Bukivna, rej. tłumacki, obw. ivano-frankivs'ki. Kurhan 1. Naczynia in situ

Fig. 10. Bukivna, Tlumač reg., Ivano-Frankivsk Prov. Barrow 1. Vessels in situ 
$A A_{1} \mathrm{ANA}_{2} \mathrm{MHO}$
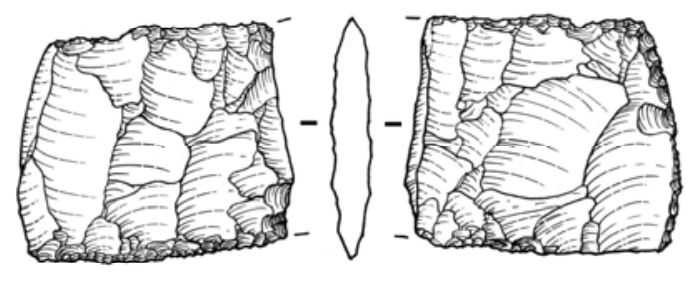

5

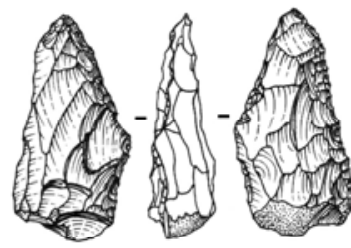

4
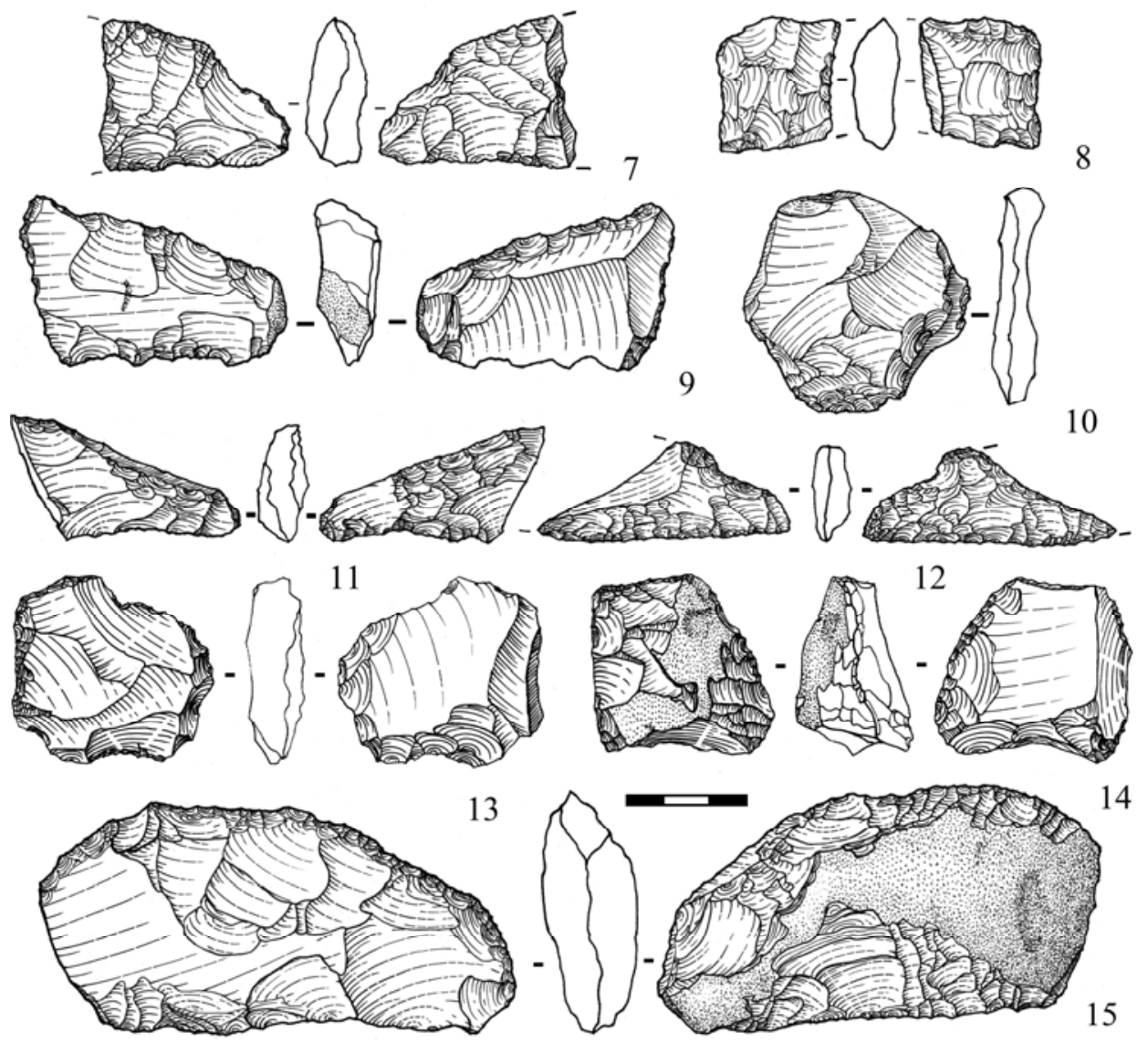

Ryc. 11. Bukivna, rej. tłumacki, obw. ivano-frankivs'ki. Wybór wyrobów krzemiennych z kurhanu 1 Fig. 11. Bukivna, Tlumač reg., Ivano-Frankivsk Prov. Selection of flint artefacts from barrow 1 
W zestawie pojemników (ryc. 9) udokumentowano 16 garnków esowatoprofilowych i ,tulipanowatych" (trzy z nich z uchami poziomo przekłutymi, jedno $\mathrm{z}$ uchem pionowo przekłutym), dziewięć waz (trzy z uchami) - w tym egzemplarz miniaturowy z uchwytami-uszkami, sześć mis różnych typów (jedna z guzamiuchwytami) oraz trzy puchary doniczkowate. Dwa naczynia zachowały się w postaci skupienia fragmentów, których nie udało się zrekonstruować. Wątki zdobnicze wykonano technikami rycia, kłucia, plastyczną i odciskania. Pokrywają one całą powierzchnię pojemników lub też tylko ich górną część. Dominuje ornament zwielokrotnionych żłobków poziomych, pionowych i ukośnych, zaszrafowanych trójkątów (najczęściej są to kombinacje wymienionych elementów zdobniczych), a także krókie kreski ryte poziome i ukośne, guzy i dookolne listwy plastyczne. Naczynia są dobrze wypalone, mają angobowaną lub wygładzoną powierzchnię zewnętrzną. Do masy ceramicznej dodano domieszkę drobnoziarnistego tłucznia kamiennego, rzadziej krzemiennego, niekiedy również miki.

We wschodniej części kurhanu, na różnej głębokości w całym nasypie, zarejestrowano nieliczne, drobne, przepalone kości. Koncentrowały się one głównie między obiektami 1 i 2 (na południe i wschód od obiektu 1 i na południe od obiektu 2). Żadnej kości nie znaleziono natomiast w naczyniach.

Wyroby krzemienne odnotowano głównie w nasypie; około 200 z nich można łączyć z działalnością budowniczych kurhanu ${ }^{15}$. Artefakty z neolitu i eneolitu dostały się do nasypu razem z darnią podczas wznoszenia kopca. Wśród wyrobów z epoki brązu znajdują się odłupki, fragmenty rdzeni, narzędzia i ich półwytwory. Zarejestrowano również kilka półwytworów bifacjalnych wkładek do sierpów (ryc. 11: 6-7, 9-15) oraz cztery wkładki ukończone, ze śladami używania - widocznymi na krawędziach pracujących (ryc. 11:5, 8). W zbiorze odnotowano dwa grociki strzał. Pierwszy z nich, zachowany fragmentarycznie, był retuszowany powierzchniowo (ryc. 11: 2). Drugi egzemplarz wykonano na odłupku z półprzezroczystego surowca kredowego o barwie ciemnoszarej. Miał on formę trójkątną, z głęboką półokrągłą wnęką w podstawie (ryc. 11: 1). Udokumentowano także dwa półprodukty grocików strzał (ryc. 11: 3-4). Wśród innych narzędzi można wymienić przekłuwacz wykonany na odłupku, dwa tłuczki (jeden na wykorzystanym wcześniej rdzeniu odłupkowym), dwa retuszery na odłupkach oraz fragment narzędzia odłupkowego (silnie przepalony).

Wśród wyrobów brązowych lepiej zachowana była szpila, o długości $30 \mathrm{~cm}$ (ryc. 12: 1), zarejestrowana na wschód o kenotafu (część wyposażenia grobowego?). Miała blaszkowatą, częściowo zniszczoną, romboidalną główkę. Długość nóżki wynosiła $24 \mathrm{~cm}$, rozmiary zachowanej części główki $-6 \times 4 \mathrm{~cm}$, jej grubość 1-1,5 mm. Główka była zdobiona czterema ,perełkowatymi” wypustkami ułożonymi w formę

\footnotetext{
${ }^{15}$ Razumov, Lysenko, Makarowicz 2012, 282 n.
} 
kwadratu. Miała zaokrąglone, lekko zawinięte narożniki. Przy jednej z górnych wypustek widniał otwór o średnicy około $1 \mathrm{~mm}$. Fragment główki uległ wykruszeniu podczas oczyszczania; pierwotnie miała on prawdopodobnie kształt wydłużonego rombu. Górna część nóżki była tordowana - skręcona zgodnie $\mathrm{z}$ ruchem wskazówek zegara. W tym miejscu była ona kwadratowa w przekroju, o rozmiarach $4 \times 4 \mathrm{~mm}$. Pozostała jej partia była okrągła w przekroju, miała średnicę $4 \mathrm{~mm}$. Drugi zabytek - niewielka zawieszka - był zniszczony w stopniu uniemożliwiającym jego rekonstrukcję.

$\mathrm{Z}$ nasypu kurhanu pochodzą drobne fragmenty naczyń, które - ze względu na rodzaj ornamentu (listwy plastyczne) i wykończenie powierzchni - przypominają ceramikę typu babińskiego (mnogowalikową), jednak zamiast piasku do masy ceramicznej dodawano szamot. Nie można też określić jej relacji z komarowską wersją kręgu trzcinieckiego. W rejonie Naddniestrza nie sposób jednak wykluczyć

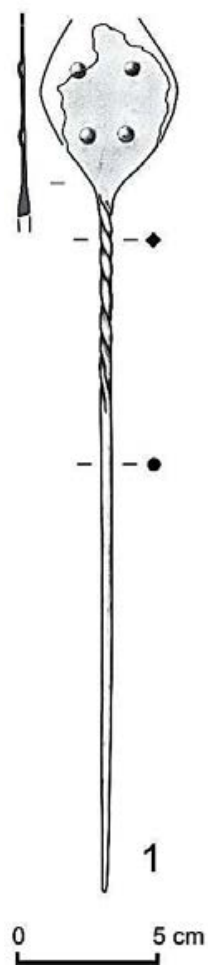

Ryc. 12. Bukivna, rej. tłumacki, obw. ivano-frankivs'ki. Szpila z główką romboidalną brązu Fig. 12. Bukivna, Tlumač reg., Ivano-Frankivsk Prov. Bronze diamond-headed pin koegzystencji wczesnych ugrupowań „,trzcinieckich" i późnych kręgu babińskiego. Podobne zjawisko czytelne jest we wschodnim areale trzcinieckiego kręgu kulturowego, w rejonie środkowego Naddnieprza i w basenie Desny ${ }^{16}$. $\mathrm{Z}$ nasypu pochodzi też kilka fragmentów ceramiki kultury pucharów lejkowatych.

\section{SEKWENCJA CZYNNOŚCI RYTUALNYCH}

Bardzo interesująca poznawczo jest obrzędowość pogrzebowa udokumentowana w charakteryzowanym kopcu. Obiekt grobowy 3 (kenotaf) był konstrukcją kamienno-drewnianą, zbudowaną z kamieni morenowych i desek. Nie zawierał żadnych kości, natomiast w nasypie kurhanu, na różnej głębokości, rejestrowano drobne przepalone kości. Materiały z kurhanu 1 pozwalają stwierdzić, że nie rozrzucono ich

\footnotetext{
${ }^{16}$ Lysenko 2007, 345 n.
} 
chaotycznie, lecz znajdowały się one w określonych sektorach kopca, na wschód od konstrukcji grobowej w obiekcie 3, między dwoma spalonymi konstrukcjami drewnianymi (obiekty 1 i 2). Niewykluczone, że w procesie budowy nasypu do jamy (obiektu 5) zsypano przepalone kości.

Należy podkreślić, że w żadnym naczyniu nie zarejestrowano kości, nie były to więc urny grzebalne. Pogląd z lat 30. XX w., powtarzany następnie po wojnie, o praktykowaniu ciałopalenia popielnicowego w Bukównej, należy więc zakwestionować. Badacze z UJK we Lwowie mylili się w interpretacji roli naczyń znajdowanych w nasypach kurhanów, uznając każde $\mathrm{z}$ nich za oddzielny pochówek ciałopalny ${ }^{17}$.

Sekwencja czynności związanych z rytuałami pogrzebowymi wyglądała następująco. Kurhan zbudowano na niewielkim wzniesieniu. W części zachodniej wykopano płytką jamę, na jej dnie usytuowano obiekt 3 (kenotaf) o konstrukcji kamienno-drewnianej. Obok niego umieszczono szpilę, zawieszkę i osprzęt łuczniczy (?), po którym pozostał tylko grocik strzały. Konstrukcję zapewne spalono, o czym świadczą przepalone fragmenty desek w części północnej. Na poziomie próchnicy pierwotnej, w różnych sektorach kopca, ustawiono pierwsze naczynia (rodzaj ofiary zakładzinowej?). W sektorach NW i NE zbudowano konstrukcje drewniane (obiekty 1 i 2). Na deskach wspomnianych struktur umieszczono naczynia, po czym je spalono. Nasyp wznoszono etapami z cegiełek - wałków darni wyciętej wokół kurhanu. Układano je obok siebie, stopniowo formując płaszcz kurhanu. Czynnościom tym towarzyszyło dalsze deponowanie naczyń w różnych partiach kopca i palenie ognisk, po których zostały ślady spalenizny i węgle drzewne. Między obiektami 1 i 2 oraz wokół nich „rozsiano” drobne, przepalone kostki. Nie była to czynność jednorazowa, gdyż kości zarejestrowano na różnej głębokości. Niektóre naczynia rozbito intencjonalnie. Zapewne podczas ceremonii pogrzebowej w nasypie kurhanu znalazły się narzędzia, półwytwory i odpady krzemienne (jako efekty działań towarzyszących „rytuałom przejścia”?). Z tego etapu pochodzą też pozostałe obiekty wziemne - relikty bliżej nieokreślonych czynności funeralnych, usytuowane w niższych partiach nasypu.

Liczne ślady aktywności społeczności „komarowskiej” świadczą, że rytuał pogrzebowy zaobserwowany w charakteryzowanym kurhanie był niezwykle złożony. Kopiec wznosiła zapewne cała lokalna wspólnota. Relikty uczty pogrzebowej „tryzny” - widoczne są na różnej głębokości nasypu, stąd można wnosić, że czynności te trwały przez dłuższy czas.

\section{ANALIZY SPECJALISTYCZNE - WSTĘPNE REZULTATY}

Artefakty, które uzyskano w trakcie badań cmentarzyska, poddano specjalistycznym ekspertyzom w Polsce i na Ukrainie. Wykonano analizy radiowęglowe,

\footnotetext{
${ }^{17}$ Bryk 1932, 22; Rogozińska 1959, 98.
} 
Tabela 1. Bukivna, rej. tłumacki, obw. ivano-frankivs'ki. Zestawienie dat radiowęglowych

Table 1. Bukivna, Tlumač reg., Ivano-Frankivsk Prov. Collation of radiocarbon dates

\begin{tabular}{|c|c|c|c|c|c|}
\hline $\mathrm{Nr}$ & Kontekst & $\begin{array}{l}\text { Datowany } \\
\text { materiał }\end{array}$ & $\begin{array}{c}\text { Oznaczenie } \\
\text { laboratorium }\end{array}$ & $\mathrm{BP}$ & $\mathrm{BC}$ \\
\hline 1 & Kurhan 2, WM IV, obiekt 1 & gleba z węglem & $\mathrm{Ki}-16740$ & $4330 \pm 570$ & $\begin{array}{l}1 \sigma 3700-2200 \\
2 \sigma 4400-1500\end{array}$ \\
\hline 2 & Kurhan 1, naczynie 34 & $\begin{array}{l}\text { ziemia z nagarem } \\
\text { z dna naczynia }\end{array}$ & Ki-16737 & $3990 \pm 270$ & $\begin{array}{l}1 \sigma 2900-2100 \\
2 \sigma 3400-1700\end{array}$ \\
\hline 3 & Kurhan 1, sektor NE & spalone kości & Ki-16736 & $3950 \pm 370$ & $\begin{array}{l}1 \sigma 2950-1900 \\
2 \sigma 3500-1500\end{array}$ \\
\hline 4 & $\begin{array}{l}\text { Kurhan } 1 \text {, sektor NW, } \\
\text { obok szpili }\end{array}$ & gleba z węglem & $\mathrm{Ki}-16739$ & $3640 \pm 270$ & $\begin{array}{l}1 \sigma 2500-1650 \\
2 \sigma 2900-1400\end{array}$ \\
\hline 5 & Kurhan 1, sektor SE, WM V & gleba z węglem & Ki-16738 & $3540 \pm 270$ & $\begin{array}{l}1 \sigma \frac{2300-1500}{2 \sigma 2700-1100}\end{array}$ \\
\hline 6 & $\begin{array}{l}\text { Kurhan } 1 \text {, sektor NW, } \\
\text { obiekt } 3\end{array}$ & gleba z węglem & $\mathrm{Ki}-16735$ & $3440 \pm 170$ & $\begin{array}{l}1 \sigma \underline{1950-1520} \\
2 \sigma 2300-1300\end{array}$ \\
\hline 7 & $\begin{array}{l}\text { Kurhan } 1 \text {, sektor NE, } \\
\text { WM IV obiekt } 2\end{array}$ & węgiel (dąb) & Poz-39759 & $3410 \pm 35$ & $\begin{array}{cc}1 \sigma & \frac{1750-1664(65,4 \%)}{1649-1643(2,8 \%)} \\
2 \sigma & 1872-1844(5,0 \%) \\
& 1813-1802(1,3 \%) \\
& 1777-1619(89,1 \%)\end{array}$ \\
\hline 8 & $\begin{array}{l}\text { Kurhan } 1 \text {, } \\
\text { sektor NW, obok szpili }\end{array}$ & węgiel (dąb) & Poz-39762 & $3290 \pm 30$ & $\begin{array}{c}1 \sigma \quad 1609-1526(68,2 \%) \\
2 \sigma 1661-1654(0,8 \%) \\
1639-1497(94,6 \%)\end{array}$ \\
\hline 9 & $\begin{array}{l}\text { Kurhan 1, } \\
\text { sektor SE, WM IV obiekt } 1\end{array}$ & węgiel (olsza) & Poz-39760 & $3260 \pm 35$ & $\begin{array}{c}1 \sigma 1608-1571(23,8 \%) \\
1561-1547(7,6 \%) \\
2 \sigma \underline{1541-1496(36,8 \%)} \\
\underline{1620-1450(95,4 \%)}\end{array}$ \\
\hline
\end{tabular}

WM - warstwa mechaniczna

paleopedologiczne, paleobotaniczne, dendrologiczne oraz składu chemicznego metalu. Kolejne ekspertyzy są w trakcie realizacji.

W laboratoriach radiowęglowych w Kijowie i Poznaniu wykonano osiem datowań materiału organicznego z omawianego kurhanu ${ }^{18}$. Daty ${ }^{14} \mathrm{C}$ uzyskane z węgielków zmieszanych z glebą i ze spalonych kości w Kijowskim Laboratorium Radiowęglowym mają zbyt duży błąd standardowy, dlatego nie wzięto ich pod uwagę przy określaniu chronologii.

\footnotetext{
${ }^{18}$ Datowanie radiowęglowe przepalonych kości i gleby zawierającej węgiel drzewny z kurhanu 1 wykonali w Kijowskim Laboratorium Radiowęglowym N.N. Kovaliuch i V.V. Skripkin; spalone węgle z obu konstrukcji drewnianych (obiekty 1 i 2 ) i z okolic depozytu ze szpilą z kurhanu 1 wykonał T. Goslar z Poznańskiego Laboratorium Radiowęglowego.
} 
Trzy oznaczenia ${ }^{14} \mathrm{C}$ uzyskane $\mathrm{z}$ węgla drzewnego (dębu i olszy ${ }^{19}$ ), pochodzącego z obu konstrukcji drewnianych (obiekty 1 i 2), oraz węgla drzewnego, pobranego spod szpili (wyposażenie z obiektu 3?), skalibrowano za pomocą programu Oxcal v. 3.10 i v. 4.1 .5 (tab. 1). Dwa oznaczenia wykonano z dębu (dlatego należy liczyć się z efektem ,starego węgla”), jedno z olszy. Suma prawdopodobieństwa łącznie skali-

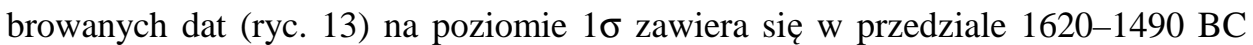
$(54,9 \%)$. Oznaczenia te są zgodne ze wstępną analizą stylistyki ceramiki naczyniowej oraz wyrobów z brązu, wskazującą na początkowe fazy rozwoju kultury komarowskiej $^{20}$.

Wyniki analizy paleopedologicznej ${ }^{21}$ wyjaśniły budowę nasypu kurhanu, rodzaj gleby oraz warunki klimatyczne w odcinku subboreału, w którym wzniesiono kopiec. W jego spągu znajdowała się warstwa gleby darniowej z dawnej powierzchni

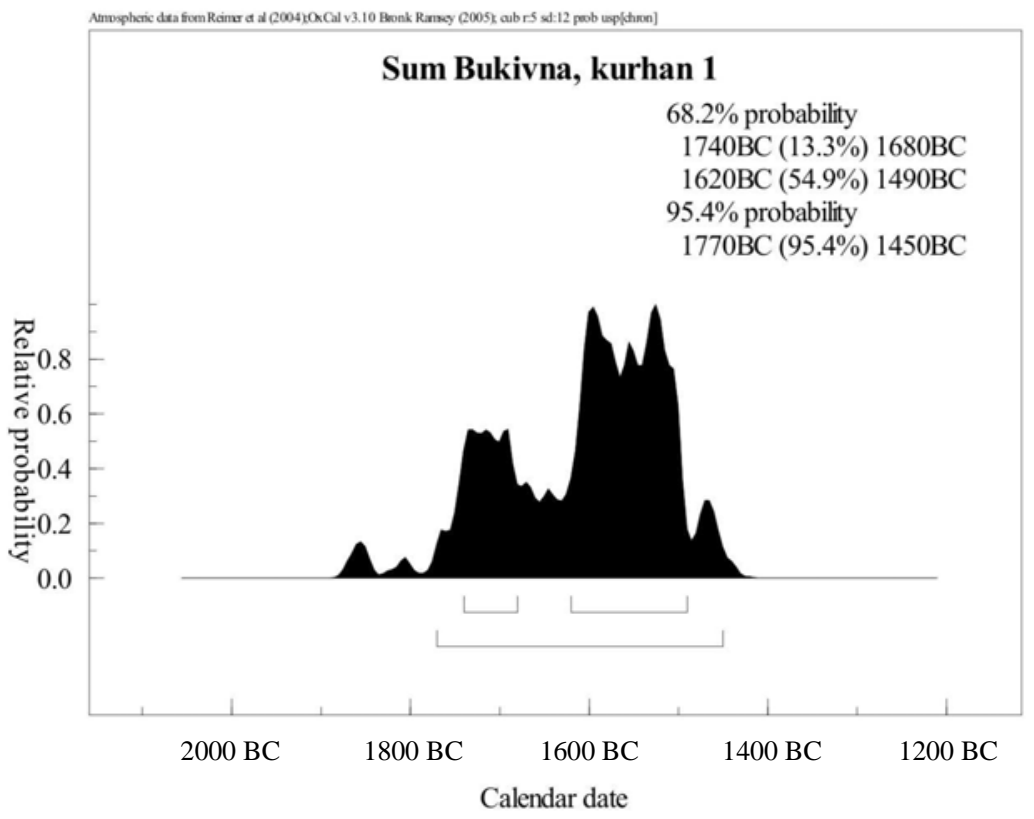

Ryc. 13. Bukivna, rej. tłumacki, obw. ivano-frankivs'ki. Suma dystrubucji prawdopodobieństwa oznaczeń radiowęglowych z Poznańskiego Laboratorium Radiowęglowego

Fig. 13. Bukivna, Tlumač reg., Ivano-Frankivsk Prov. The sum of probability distribution of radiocarbon dates from the Poznań Radiocarbon Laboratory

\footnotetext{
${ }^{19}$ Analizę dendrologiczną drewna z obu konstrukcji wykonał T. Stępnik z Pracowni Uni-Arch w Poznaniu.

${ }^{20}$ Swiesznikow 1967; Sulimirski 1968.

${ }^{21}$ Analizę gleby (badania makro- i mikromorfologiczne) wykonali pracownicy Instytutu Geografii Narodowej Akademii Nauk Ukrainy w Kijowie - Ż.N. Matviišyna i A.G. Parchomienko.
} 
(próchnica pierwotna). Wyżej zalegała gleba, którą przykryła mulista warstwa z podglebia. Usunięcie darni doprowadziło do powstania rowka wokół kopca, wyraźnie widocznego na obecnej powierzchni. Gleby, na których wzniesiono kurhany 1 i 2, określono jako czarnoziemy wyługowane lub spopielane, które rozwijały się pod roślinnością łąkową w ciepłym, umiarkowanym klimacie, z dostateczną ilością opadów.

Podczas przemywania ziemi z przydennej części naczynia 14 znaleziono zwęglony ziarniak jęczmienia ${ }^{22}$.

Ozdoby brązowe były silnie skorodowane, nie było zatem możliwe pobranie próbek z części „czystych” przedmiotów. Aby określić w przybliżeniu skład chemiczny, wykonano analizę spektralną produktów korozji ${ }^{23}$ (tab. 2). Poddano jej skorodowane fragmenty zawieszki, nóżki i główki szpili z kurhanu 1. W rezultacie można stwierdzić, że do produkcji wykorzystano brąz cynowy. Wysoki udział cyny należy tłumaczyć tym, że w skorodowanym brązie w pierwszej kolejności ujawnia się stały stop cyny i miedzi. W skład przedmiotów wchodziły też, w znacznej ilości, pierwiastki śladowe - arsen, srebro i cynk.

Tabela 2. Bukivna, rej. tlumacki, obw. ivano-frankivs'ki. Rezultaty analizy spektralnej wyrobów z brązu Table 2. Bukivna, Tlumač reg., Ivano-Frankivsk Prov. Results of spectral analysis of bronze items

\begin{tabular}{|l|c|c|c|c|c|c|c|c|c|c|c|c|}
\hline Przedmiot & $\begin{array}{c}\mathrm{Nr} \\
\text { analizy }\end{array}$ & $\mathrm{Sn}$ & $\mathrm{Pb}$ & $\mathrm{Zn}$ & $\mathrm{Bi}$ & $\mathrm{Ag}$ & $\mathrm{Sb}$ & $\mathrm{As}$ & $\mathrm{Fe}$ & $\mathrm{Ni}$ & $\mathrm{Co}$ & $\mathrm{Au}$ \\
\hline $\begin{array}{l}\text { szpila, } \\
\text { kurhan 2 }\end{array}$ & 385 & 54,07 & - & 0,158 & - & 1,154 & 0,642 & 1,715 & 0,272 & - & - & 0,045 \\
\hline $\begin{array}{l}\text { szpila, } \\
\text { kurhan 1 }\end{array}$ & 386 & 78 & 0,047 & 0,117 & 0,008 & 0,204 & - & 2,346 & 1,741 & - & - & 0,047 \\
\hline $\begin{array}{l}\text { zawieszka, } \\
\text { kurhan 1 }\end{array}$ & 387 & 77,95 & - & 0,062 & - & 0,056 & - & 0,089 & 5,117 & - & - & - \\
\hline
\end{tabular}

\section{WNIOSKI}

Wyniki badań kurhanu $1 \mathrm{w}$ Bukivnej przyniosły wiele interesujących obserwacji. Udokumentowana $\mathrm{w}$ nim konstrukcja grobowa $\mathrm{z}$ kamieni morenowych nie ma ścisłych analogii na innych cmentarzyskach „komarowskich”. Groby podkurhanowe $\mathrm{z}$ elementami kamiennymi występują w niektórych kurhanach na eponimicznym stanowisku tego ugrupowania w Komarowie (np. kurhany 14, 20, 48, 50), są to jednak konstrukcje o innej budowie formalnej. Podobne do kenotafu $\mathrm{z}$ analizowanej nekropoli są groby z cmentarzyska beznasypowego z epoki brązu w Kivitkalnse na

\footnotetext{
${ }^{22}$ Analiza G.A. Paškievič z Instytutu Archeologii Narodowej Akademii Nauk Ukrainy w Kijowie.

${ }^{23}$ Analizę składu chemicznego wyrobów z brązu sporządziła T.N. Goško z Instytutu Archeologii Narodowej Akademii Nauk Ukrainy w Kijowie.
} 
Litwie $^{24}$. Były one zbudowane z kamieni oraz kłód dębowych, w których znajdowały się szkielety. W grobach 32 i 41 znaleziono fragmenty naczyń, które przypominają ceramikę typu „,trzcinieckiego",25.

Obecność społeczności kręgu trzcinieckiego na Litwie jest bezsporna ${ }^{26}$. Wiele stanowisk „trzcinieckich” z tej strefy wymieniają R. Rimantienè i T. Ostrauskas ${ }^{27}$. Podobieństwa konstrukcji grobowych w Bukivnej i Kivitkalnse mogą wskazywać na związki górnego Naddniestrza i rejonu nadbałtyckiego w starszej epoce brązu. Przytoczone analogie należy jednak traktować jako ,hipotezę roboczą", wymagającą weryfikacji lub falsyfikacji w toku dalszych badań.

Bliższe przestrzennie są analogie do drewnianych konstrukcji z Bukivnej (obiekty 1 i 2) i z rozległej nekropoli ludności kręgu trzcinieckiego w Guciowie nad Wieprzem. Odkryto w niej obiekty zbudowane z desek o analogicznym kształcie i zbliżonych proporcjach ${ }^{28}$. Podobnie jak w kopcach na omawianym cmentarzysku, występowały one nie w centrum kurhanu, lecz w pewnym oddaleniu od niego.

Kurhany z badań w Bukównej i Komarowie w latach 30. XX w. łączono z fazą I ${ }^{29}$ lub I i II rozwoju kultury komarowskiej ${ }^{30}$. Na podstawie analizy stylistycznej można do tego okresu zaliczyć również zestaw ceramiki z badanego kopca. Chronologię uściślają otrzymane daty ${ }^{14} \mathrm{C}$, wskazujące na drugą ćwierć II tys. BC jako okres jego budowy.

Polsko-ukraińskie badania cmentarzyska kultury komarowskiej w Bukivnej są realizowane w ramach projektu Narodowego Centrum Nauki (2012-2015). Do 2012 r. rozpoznano trzy kopce z grupy kurhanowej I. Oprócz zbadania kopca 1 dokończono eksplorację kurhanu 2, zbadano także kurhan 3. Wykonano wiele dalszych analiz specjalistycznych: paleobotanicznych, palinologicznych, dendrologicznych, paleopedologicznych, fizykochemicznych i radiowęglowych. W 2013 r. planowane jest rozpoznanie dwóch kopców, mierzących ponad $3 \mathrm{~m}$, z dwóch pozostałych grup. Wyniki tych badań będą sukcesywnie prezentowane w kraju i za granicą.

\section{BIBLIOGRAFIA}

Bryk J.

1932 Tymczasowe sprawozdanie $\mathrm{z}$ badań archeologicznych w Bukównie, pow. tłumacki, Sprawozdania Polskiej Akademii Umiejętności 37/5, s. 21-22.

\footnotetext{
${ }^{24}$ Denisova, Graudonis, Gravere 1985, tabl. XXIII-XXIV.

${ }^{25}$ Denisova, Graudonis, Gravere 1985, 45, tabl. IV: 5-6.

${ }^{26}$ Makarowicz 2010b.

${ }^{27}$ Rimantiené, Ostrauskas 1998, Abb. 1:20

${ }^{28}$ Dziękujemy dr. Jackowi Górskiemu, Dyrektorowi Muzeum Archeologicznego w Krakowie, za możliwość wglądu w dokumentację dotyczącą stanowiska oraz cenne uwagi.

${ }^{29}$ Swiesznikow 1967, 73.

${ }^{30}$ Sulimirski $1968,93$.
} 
Denisova R.J., Graudonis J.J., Gravere R.U.

1985 Kivutkalnskij mogilnik epochi bronzy, Riga.

Florek M., Taras H.

2003 Dacharzów. Cmentarzysko kultury trzcinieckiej, Lublin.

Górski J.

1996 Uwagi o znaczeniu kurhanów dla społeczności kultury trzcinieckiej z obszarów lessowych zachodniej Małopolski [w:] Problemy epoki brazu i wczesnej epoki żelaza w Europie Środkowej. Księga jubileuszowa poświęcona Markowi Gedlowi, red. J. Chochorowski, Kraków, s. 204-211.

2010 Niektóre elementy symboliczne w kurhanach kultury trzcinieckiej [w:] Mente et rutro. Studia archaeologica Johanni Machnik viro doctissimo octogesimo vitae anno ab amicis, collegis et discipulis oblata, red. S. Czopek, S. Kadrow, Rzeszów, s. 369-378.

Gudowski J.

2007 Z biegiem Dniestru, Warszawa.

Kempisty A.

1967 Wyniki badań kopca I w Miernowie pow. Pińczów [w:] Metodyka naukowo-techniczna badań archeologicznych i antropologicznych. Rozprawy Zespołu Badań nad Polskim Średniowieczem UW i PW, t. 4, Warszawa, s. 147-175.

1978 Schyłek neolitu i początek epoki brazu na Wyżnie Matopolskiej w świetle badań nad kopcami, Warszawa.

Kośko A.

2011 Od nadwarciańskiego matecznika ku archeologii pogranicza Zachodu i Wschodu Europy, Folia Praehistorica Posnaniensia 16, s. 479-490.

Lysenko S.D.

2007 Dinamika razvitija tszineckogo kulturnogo kruga na granice pravoberežnoj lesostepi i Poles'ja [w:] Wspólnota dziedzictwa archeologicznego ziem Ukrainy i Polski, red.

L. Bakalarska, Warszawa, s. 341-389.

Lysenko S.D., Makarowicz P.

2013 Predvaritelnyje rezultaty issledovanij mogilnika Bukovna v 2010 g., Materiały z międzynarodowej konferencji naukowej „Gordiivskij kurgannyj mogilnik jak zagalnoevropeiskij kulturnyj fenomen”, Vinnica, Ukraina, 29-01.10.2011, Vinnica 2013 [w druku].

Lysenko S.D., Makarowicz P., Lysenko S.S., Goško T.J.

2011 Metallieskije izdelija iz kurganov komarovskoj kultury mogilnika Bukovna [w:] Archeologija i davna istorija Ukraini, vol. 8, Kiïv, s. 38-42.

Lysenko S.D., Makarowicz P., Kokin I.T., Šklarevskij E.I.

2011 Predvaritelnyje rezultaty issledovanij mogilnika Bukowna [w:] Archeologični Doslidžennja v Ukraini 2010 r., Kiïv-Poltava, s. 226-228.

Makarowicz P.

2008 Elitarne pochówki z kurhanu komarowskiego w Ivanju na Wołyniu - zarys możliwości interpretacyjnych [w:] Na pograniczu światów. Studia z pradziejów międzymorza bałtycko-pontyjskiego ofiarowane Profesorowi Aleksandrowi Kośko w 60. rocznicę urodzin, red. J. Bednarczyk, J. Czebreszuk, P. Makarowicz, M. Szmyt, Poznań, s. 333-352.

2009 Baltic-Pontic Interregional Routes at the Start of the Bronze Age [w:] Routes Between the Seas: Baltic - Boh - Bug - Pont from the $3^{\text {rd }}$ to the Middle of the $1^{\text {st }}$ Millennium BC, Baltic-Pontic Studies 14, red. A. Kośko, V. Klochko, Poznań, s. 301-336.

2010a The Creation of new social space. Barrows of the Corded Ware Culture and Trzciniec Circle as markers of a mental map in the upland parts of Poland and western Ukraine [w:] Landscapes and Human Development: The Contribution of European Archaeology. 
Proceedings of the International Worksop "Socio-environmental dynamics over the last 12,000 years: The creation of landscapes, $\left(1^{\text {st }}-4^{\text {th }}\right.$ April 2009)", Universitätsforschungen zur Prähistorischen Archäologie 191, red. Kiel Graduate School "Human Development in Landscapes", Bonn, s. 203-215.

2010b Trzciniecki krag kulturowy - wspólnota pogranicza Wschodu i Zachodu Europy, Poznan.

2012 Ekspedycja górnodniestrzańska Instytutu Prahistorii Uniwersytetu im. Adama Mickiewicza w Poznaniu. Perspektywy polsko-ukraińskiego projektu badawczego, Folia Praehistorica Posnaniensia 17, s. 287-302.

Makarowicz P., Lysenko S., Kočkin I.

2013 Wyniki badań cmentarzyska kultury komarowskiej w Bukivnej nad górnym Dniestrem w 2010 roku, Materiaty Archeologiczne 29, s. 101-120.

Rimantienė R., Ostrauskas T.

1998 Dem Trzciniec gleichzeitige Sidlungen in Lituaen [w:] „Trzciniec” - system kulturowy czy interkulturowy proces?, red. A. Kośko, J. Czebreszuk, Poznań, s. 203-215.

Razumov S.N., Lysenko S.D., Makarowicz P.

2012 Kremien' iz kurgana 1 mogilnika Bukovna: slučainost' ili ritual? [w:] Čelovek v istorii $i$ kulture, vypusk 2, red. A.A. Priganin, Odessa, s. 282-289.

Rogozińska R.

1959 Cmentarzysko kultury komarowskiej w Bukównie, Materiały Archeologiczne 1, s. 97-114.

Siwkówna I.

1937 Tymczasowe wyniki badań terenowych w Bukównej, pow. tłumacki, Z otchłani wieków 13, s. 67-70.

Sulimirski T

1964 Barrow-Grave 6 at Komarów, University of London Institute of Archaeology Bulletin 4, s. $171-188$

1968 Corded Ware and Globular Amphorae North-East of the Carpathians, London.

Svešnikov I.K.

1968 Bogatyje pogrebenija komarovskoj kultury u s. Ivan'ja rovenskoj obłasti, Sovetskaja Archeologija 2, s. 159-168.

Swiesznikow I.

1967 Kultura komarowska, Archeologia Polski 12/1, s. 39-107.

Zagalnogegrafičnyj atlas...

Zagalnogegrafičnyj atlas Ukraini, Kiïv 2004.

Zastavnyj F., Kusiński W.

2003 Ukraina. Przyroda - Ludność - Gospodarka, Warszawa.

\section{BRONZE AGE BARROWS IN THE UPPER DNIESTER BASIN - POLISH-UKRAINIAN} RESEARCH PROJECTS

\section{S u m m a r y}

The Upper-Dniester expedition from Institute of Prehistory, Adam Mickiewicz University in Poznan, works on two projects. The first of them, "Bukivna. Elite necropolis of Komarów culture upon the Dniester river", refers to fieldwork (non-invasive and excavation) and analyses of a vast 
Bronze Age cemetery. It is financed with a grant of the National Science Centre. The second project, started in 2013 and financed by the National Programme for the Development of Humanities is titled "Catalogue of barrow cemeteries of the Komarów culture in the upper Dniester basin (former Stanisławów province)". It includes recognition, non-invasive investigation and cataloguing of several necropolises discovered before World War II. This article refers to the first of the two projects.

The barrow cemetery in Bukivna (former Bukówna) in Ukraine is one of more important necropolises of Komarów culture of the Trzciniec cultural circle. The history of its recognition dates back to the 1930s and was connected with the excavations carried out by archaeologists from the Jan Kazimierz University in Lwow. The investigation was restarted in 2010 on the basis of agreements between the University, the Institute of Archaeology of the National Academy of Sciences of Ukraine in Kiev and the Chair of Ethnology and Archaeology of the Institute of History and Political Science of the SubCarpathian National University in Ivano-Frankivs'k. The site was situated on the upper Dniester, about $1.5 \mathrm{~km}$ from the river bed, on its right bank, along the edge of the plateau (Fig. 1). The barrows occured in three main concentrations, from north to south along the Bukivna, about $1 \mathrm{~km}$ to the west. These structures were built in line (straight-line-group) covering area of over several hundred meters (Figure 2-4). The article discusses synthetically the preliminary results of the study of barrow 1 .

Barrow 1 (Figs. 5 and 6) was piled on a natural hill, on the west smoothly passing into the flat area. The barrow was slightly oval, oriented NNE-SSW. The actual height of the embankment was about $1.3 \mathrm{~m}$, and its dimensions (length to width) measured at a depth of $1.3 \mathrm{~m}$ from the highest point $-15 \times 13 \mathrm{~m}$. Around the barrow, especially from the south and west, there was visible a semicircular hollow, 4-5.5 $\mathrm{m}$ wide, where the soil (turf) for its construction had been taken from.

Monument consisted (as seen from the top) with a thin, several-centimetre thick, layer of contemporary humus, with a layer of light gray loess underneath, $20-40 \mathrm{~cm}$ thick. Below there was the appropriate embankment, with a thickness of up to approximately $90 \mathrm{~cm}$, built of rolled bricks of turf, brown and brown-dark gray, cut out from around the barrow and arranged tightly alongside one another and one above the other ("rolled divider"). It was heavily infiltrated by the roots. Below was a uniformly black and brown layer of primary humus about $60 \mathrm{~cm}$ thick, under which there was a bedrock - "clayish" loess.

In the discussed barrow there were six features and over 400 artefacts documented, including 38 vessels in several deposits (Figs. 6, 9 and 10), 262 flint implements (Fig. 11), several large pieces of structural daub, and bronze items - a pin (Fig. 12) and a damaged pendant. Among the features there were recorded two wooden structures (ritual objects?) and one of stone and wood (cenotaph?) (Figs. 7 and 8). South- and eastwards of feature 1 and southwards of feature 2 a small amount of burned bones was recorded. In both eastern areas they occurred at different depths throughout the whole embankment, but were more concentrated in its central part.

Bronze tools were heavily corroded, hence it was not possible to take samples from their "clean" parts. To determine the approximate chemical composition, spectral analysis has been performed of the products of corrosion (Table 1). The subject of this analysis were corroded fragments of the pendant, the head and body of a pin from barrow 1, and the surface of the head of a pin from barrow 2. They were made of tin bronze. However, they also included, in substantial amounts, trace elements - arsenic, silver, and zinc. 
Three ${ }^{14} \mathrm{C}$ dates were obtained from charcoal (oak and alder) derived from wooden structures in the barrow 1 (features 1 and 2) and from the charcoal collected from underneath the pin (grave goods from feature 3?). They were calibrated using program $O x c a l v .3 .10 \mathrm{i}$ v. 4.1.5. and provided dates between 1750 and $1500 \mathrm{BC}$ (Table 2). Two older dates were obtained from coal oak, so the "old carbon" effect should be suspected, while the younger of alder. Summed probability distribution of calibrated dates (Fig. 13) at the level of $1 \sigma$ fits within the range between 1620 and $1490 \mathrm{BC}$ (54.9\%).

In none of the vessels bones were registered, thus they were not urns. Therefore, information about the presence of cremation urns in Bukivna from the 1930s then repeated after the war, should be verify negatively.

Translated by Lucyna Leśniak 